\title{
COBRIR E MOSTRAR A CARA: A RECUPERAÇÃO DO ROMANCE HISTÓRICO NO SÉCULO XXI EM TORTO ARADO DE ITAMAR VIEIRA JÚNIOR E FORMAS DE VOLTAR PARA CASA DE ALEJANDRO ZAMBRA
}

\author{
[Covering and Showing the Face: Possibilities of Recovering Historical \\ Novel in the 21st Century in Torto Arado, by Itamar Vieira Júnior and \\ Formas de voltar para casa, by Alejandro Zambra]
}

\author{
Eliziane Navarro ${ }^{1}$ \\ Marcelo Ferraz de Paula ${ }^{2}$
}

\begin{abstract}
Resumo: O retorno ao passado é uma necessidade histórica. Mesmo em tempos que urdem a construção de uma identidade nacional e independente, sobretudo nos países colonizados, é preciso recuperar o passado, avaliar a história oficial e então reconstruí-la, considerando feitos da margem social silenciada até então. A isto se dedica o romance histórico. Este estudo visa analisar a possibilidade de recuperação do passado em dois contextos diferentes: a Ditadura Militar Chilena por meio da narrativa ficcionalizada da memória no romance Formas de voltar para casa, de Alejandro Zambra, de 2003, e a escravidão no Brasil reverberada na obra Torto Arado, de Itamar Viera Júnior, de 2018. Dentro de suas especificidades, essas abordagens do discurso histórico, esteticamente organizado, reverberam a intenção máxima do romance histórico enquanto categoria, ao conceber a história como fator diretivo das ações dos personagens, de maneira a ter na formulação de uma consciência identitária, seu fim último.
\end{abstract}

Palavras-chave: Romance histórico; Formas de voltar para casa; Ditadura Chilena; Torto Arado; Escravidão.

Abstract: The return to the past is a historical necessity. Even in times that urge the construction of a national and independent identity, especially in the colonized countries, it is necessary to recover the past, assess the official history and then reconstruct it, considering the achievements of a social margin, that was silenced until then. The historical novel is dedicated to this. This study aims to analyze the possibility of recovering the historical past in two different contexts: the Chilean Military Dictatorship through the fictionalized narrative of memory in Alejandro Zambra's novel Formas de voltar para casa, published in 2003, and the context of slavery in Brazil reverberated in the book Torto Arado, by Itamar Viera Júnior, from 2018. Within their specificities, these two approaches to historical discourse, aesthetically organized, reverberate the maximum intention of the historical novel as a category, when conceiving history as a guiding factor of actions of the characters, in order to have the ultimate end in the formulation of an identity consciousness.

Keywords: Historical Novel; Formas de voltar para casa; Chilean Dictatorship; Torto Arado; Slavery. Alguém deve rever, escrever e assinar os autos do Passado antes que o Tempo passe tudo a raso. (Cora Coralina)

\footnotetext{
1 Doutoranda no Programa de Pós-Graduação em Letras e Linguística da Universidade Federal de Goiás. E-mail: efnavarro4@gmail.com

2 Professor de Teoria Literária da Universidade Federal de Goiás (UFG) e membro do quadro permanente de professores do Programa de Pós-Graduação em Letras e Linguística (PPGLL-UFG).
} 


\section{PRIMEIRAS CONSIDERAÇÕES}

É bem possível que o narrador de Formas de voltar para casa esteja certo ao afirmar que "ler é cobrir a cara, escrever é mostrá-la" (ZAMBRA, 2014, p. 34). Isso porque ler, em primeira instância, nos obriga a conviver com o discurso que a nós é posto. Assim, toda a subversão, para o bem e para o mal, intrínseca ao ato da leitura proposto por Candido em $O$ direito à literatura (2011) é um processo inicialmente interno e pessoal, uma vez que, mesmo a oposição à uma ideia, nasce da aceitação daquilo enquanto discurso válido.

Por outro lado, o fator exposição, que subjaz ao trabalho com a escrita, atinge uma espécie de desnudamento coletivo, na medida em que o sujeito que escreve se opõe ao individualismo, abrindo-se à alteridade. Escrever, nesse sentido, é tomar partido, é ato político, é representação: dentre as muitas perspectivas pelas quais uma história pode ser contada, o escritor faz uma opção. E é por meio dessa escolha que ele reafirma ou critica, desconstrói ou sustenta, o estatuto de autoridade da história oficial.

A metáfora nos cabe ainda para discutir a evolução do romance histórico enquanto gênero dinâmico, que se molda aos interesses sociais na medida em que o mundo se transforma. São esses elementos consonantes à construção da narrativa e transformados pelas alternativas históricas de cada tempo que nos interessa nesse estudo, não sob a intenção de separá-los conforme cada período do romance em um caráter normativo, mas para entender quais ponderações históricas atravessam as escolhas dos autores.

Com essa perspectiva, interessa-nos aqui discutir conceitos básicos do romance histórico, considerando elementos do modelo tradicional, nos moldes de George Lukàcs (2009; 2011), resgatados por Mata Induraín (1995), até as especificidades do então denominado "novo romance histórico", aqui representados teoricamente por Fernando Aínsa (2003) e Seymour Mentón (1993).

No que diz respeito às obras literárias, centraremos nossa reflexão no romance Formas de voltar pra casa, publicado em 2011, que trata de um narrador e suas relações com o regime político do Chile, desde a infância durante a ditadura de Pinochet até o período adulto, no país redemocratizado, e no romance Tordo Arado (2018), de Itamar Vieira Júnior intitulado Torto Arado, cujo enredo se centra em duas irmãs que (sobre)vivem à violência em um cotidiano rural marcado pela luta pelo direito à terra. O romance, ganhador do Prêmio Leya do mesmo ano e, até agora, finalista dos prêmios Jabuti e Oceanos 2020, desconforta seus leitores ao escancarar a não efetividade da Lei Áurea, que convenientemente não chegou ao sertão do Brasil.

Embora tempo, espaço e contexto - tanto o de publicação quanto o presentificado pelos fatos históricos plasmados nas narrativas - sejam bastante diferentes, as duas obras se aproximam na medida em que servem ao resgate da memória de um aglomerado de sujeitos cujas ações deram a tônica para a construção dos fatos históricos, mas ficaram à margem da história oficial. É esse resgate que nos possibilita lançar um olhar crítico sobre o presente, principalmente considerando que o passado nos dá uma perspectiva fundamental para entender o presente. 


\section{ROMANCE HISTÓRICO (OU) QUANDO O PRIVADO ENCONTRA O PÚBLICO}

Há um substrato íntimo que interliga História e Literatura. Isso porque, além de olhar para o mesmo material, essas duas áreas têm em sua constituição o ato de recriar práticas humanas a partir da elaboração no tempo (NUNES, 1988). Essas recriações, no entanto, são produzidas de formas distintas nas duas áreas: o campo literário, por exemplo, pressupõe um processo de ficcionalização, enquanto o que sustenta o discurso historiográfico é a fundamentação das informações, já que "la historia desarrolla un discurso realista y la novela historica un discurso ficticio.” (MATA-INDURAÍN, 1995, p. 44).

De qualquer forma, é inegável que ambas podem contribuir de maneira relevante uma com a outra, como propõe Dominique Lacapra ao problematizar a relação entre textos e contextos na historiografia:

(...) a questão mais sugestiva colocada pelo romance à historiografia talvez seja se a escrita contemporânea da história pode aprender algo de natureza autocrítica, a partir de um modo de discurso que ela frequentemente tenta usar ou explicar de maneira excessivamente reducionista. Uma forma diferente de leitura de romances pode nos alertar não apenas para as vozes contestatórias e os contra-discursos do passado, mas também para as formas nas quais a própria historiografia pode se tonar uma voz mais crítica nas "ciências humanas". (LACAPRA, 1991, p. 122)

Em outros termos, seria esse acesso ao discurso aquém do oficial, possibilitado pelo romance, que aplacaria a problemática da autoridade quase dogmática da historiografia.

Esse exemplo de expressiva contribuição de uma área à outra, no entanto, não exclui o fato de que há especificidades em cada campo, pois produzem reações críticas distintas em termos de reflexões a respeito dos fatos históricos (INDURAÍN, 1995). O romance histórico intensifica e dramatiza essa relação ao colocar em seu núcleo o desafio do autor de "encontrar un equilibrio estable entre el elemento y los personajes históricos y el elemento y los personajes ficcionales, sin que uno de los dos aspectos ahogue al outro" (INDURAÍN, 1995, p. 14).

É George Lukàcs (2011) quem determina as bases para essa discussão, situando o nascimento do romance histórico no século XIX, a partir das obras de Walter Scott. Ainda que adote uma perspectiva predominantemente filosófica, é possível perceber que, para o crítico húngaro, a definição do romance histórico perpassa diversos elementos formais caracterizadores, como um contexto historiográfico com relativo distanciamento temporal, personagens históricos com comportamento condizente com o seu tempo, mas que não são os protagonistas; enredo fictício com personagens também inventados; conflitos provenientes das relações entre o que é fictício e o que é histórico. (LUKÀCS, 2011). Acerca dos elementos definidores, é importante ressaltar que é:

de la relación entre los personajes centrales fictícios, y los colaterales, de carácter histórico, derivan algunas de las claves fundamentales de la trama novelesca, que explican, por ello mismo, muchos de los comportamientos de los personajes, 
tanto reales como fictícios, así como también las soluciones que se va dando a los conflictos que a lo largo del relato se han ido presentando, hasta culminar con la solución o desenlace final" (MARQUEZ RODRIGUEZ, 1991, p. 22)

Assim, o romance instaura uma relação dinâmica entre vida pública e privada, uma interferindo na outra, na medida em que, através do acesso do personagem comum - não o herói histórico - aos fatos históricos, o leitor compreenda os sentimentos humanos da época. Portanto, não se trata somente de pôr a história como um plano de fundo, conforme diz Marquez Rodriguez em sua Historia y fición en la novela venezolana:

Para él no se trata de revivir, pura y simplesmente comportamiento de los seres humanos que actuaron en los acontecimentos que configuran ese pasado, pero sin perder de vista el carácter continuo de la historia, y por tanto la posible relación que esos comportamientos tengan con el presente. (MARQUEZ RODRÍGUEZ, 1991, p. 27)

É preciso que haja uma simbiose entre passado e presente. A história aqui é percebida enquanto construção, não como um fenômeno natural e, nessa perspectiva, o sujeito, enquanto produtor da sua história individual, se acopla a outros sujeitos também produtores de histórias individuais em um movimento histórico maior e passível à revolução. Como se o romance, por meio dessas categorias estruturais, procurasse a totalidade de um momento específico, mesmo enquanto gênero fadado à fragmentação (LUKÁCS, 2009).

Se são as circunstâncias histórico-sociais que determinam o nascimento do romance histórico (MATA-INDURAÍN, 1995), são também elas que o transformarão com o decorrer do tempo. Para dar conta dessas transformações, o olhar eurocêntrico do esquema tradicional é contraposto às produções das ex-colônias, onde a ânsia por uma revisão dos acontecimentos históricos alcança inúmeros intelectuais, cujo compromisso com a construção de uma consciência nacional demanda, a rigor, a constante subversão da história oficial, de matiz cultural e epistemologicamente hegemônico.

Seymor Mentón (1993) classifica essas tendências como o romance histórico contemporâneo ou novo romance histórico ${ }^{3}$ ou ainda romance histórico latino contemporâneo, cujas características compreendem, além da apresentação de ideias filosóficas que reverberam a impossibilidade de se conhecer a verdade histórica, a ciclicidade da história (ainda que com espaço para o imprevisível), a distorção dos fatos históricos feita de forma consciente, a intertextualidade, a metaficção, a ficcionalização dos personagens históricos e, por fim, o aparecimento dos conceitos bakhtinianos de dialogismo, carnavalização, paródia e heteroglossia (MENTÓN, 1993).

Para alcançar a criticidade esperada, o esquema contemporâneo põe em xeque os heróis históricos, a fim de humanizá-los, mostrando-os com virtudes e defeitos. Diferentemente dos heróis analisados por Lukàcs que, embora secundários, ainda se conservavam

3 Parte da crítica desconsidera essa nomenclatura por acreditar que ela denota a existência de um romance histórico em oposição ao adjetivo novo. 
intocáveis, no novo romance esse herói pode se deixar levar pelas paixões humanas. É essa rasura da história oficial que bem caracteriza o romance histórico do século XX.

\section{DUAS POSSIBILIDADES}

Diante de tantas faces possíveis, Alejandro Zambra adota o estatuto da marginalização máxima para tratar do obscuro período da ditadura militar chilena: a infância. Mais que isso, a infância no interior de uma família em que "não havia mortos nem havia livros." (ZAMBRA, 2014, p. 53). A obra revela as inquietações de um narrador que busca nas memórias do passado - a infância durante a ditadura de Pinochet - a conciliação com um presente ainda em desassossego.

A marginalização também compõe o enredo de Torto Arado, de Itamar Vieira Júnior. Nele, toda a família de Zeca Chapéu Grande, incluindo suas filhas Bibiana e Belonísia, vivem em regime de servidão na fazenda Água Negra, nos confins do sertão brasileiro. O romance, contado por três vozes distintas, Bibiana, Belonísia e a entidade que, por viver desde o Brasil colonial, se preocupa com o povo e tenta interferir na vida social, na medida em que se apossa do corpo de algumas personagens, tem início com um acidente, no qual uma das irmãs corta sua própria língua e perde para sempre a fala. No decorrer do romance, descobrimos que a que perde a língua é justamente aquela que tem uma consciência natural da situação de seu povo, mas que ficará impossibilitada de lutar pelos seus por conta da deficiência e marginalização na qual sua situação a confina.

A perspectiva de um menino que, depois de adulto, busca na história dos outros a resignificação da culpa por sua falta de inserção nos fatos históricos e de três vozes que vão descobrindo, ao longo do romance, a dimensão da estrutura política na qual estão inseridas nos permite acessar o contexto ditatorial chileno e a escravidão brasileira com autenticidade só possível em obras que alcancem o outro lado da cerca da história oficial, uma marca indelével do novo romance histórico. Nas palavras de Fernando Aínsa, em Reescribir el passado - historia e ficción en América Latina:

(...) Esta es la característica más importante de la nueva novela histórica latino-americana: buscar entre las ruinas de una historia desmantelada por la retórica y la mentira al individuo auténtico perdido detrás de los acontecimentos, descobrir y ensalzar al ser humano en su dimensión más vital, aunque parezca inventado, aunque en definitivo lo sea. (AÍNSA, 2003, p. 111-112)

É sob essa perspectiva, que elege como característica primordial à caracterização do romance histórico e a historicidade enquanto elemento determinante para um enredo composto por personagens comuns que se conscientizam da confluência entre esfera pública e privada, que propomos a análise aqui exposta.

O romance de Zambra é delimitado temporalmente por dois terremotos: um historicamente marcado como um dos mais devastadores do país, ocorrido em 3 de março de 1985; e o outro no presente da narrativa, com o país já redemocratizado. A fixação da ação em 
um passado histórico com relativo distanciamento temporal é particularidade do romance histórico, conforme Carlos Mata Induráin (1995). É importante lembrar que não se trata apenas de situar o enredo em um contexto histórico, mas de reconstruir os hábitos e a vivência da época, o que Zambra alcança na medida em que descreve o cotidiano de cuidados das famílias com as relações pessoais estabelecidas, próprio de quem (sobre)vive, dia após dia, às misérias do autoritarismo legitimado. Como quando descreve o cotidiano dos alunos da época:

(...) Havia certa beleza no gesto, pois éramos então justamente isso, personagens secundários, centenas de meninos que cruzavam a cidade mal equilibrando as bolsas de lona. Os moradores do bairro experimentavam o peso e faziam sempre a mesma piada: parece que você leva pedras na mochila. O centro de Santiago nos recebia com bombas de gás lacrimogêneo, mas não levávamos pedras e sim tijolos de Baldor ou Ville ou Flaubert. (ZAMBRA, 2003, p. 30)

Outro exemplo é a surpresa do narrador quando Claudia o convida para adentrar à sua casa, em uma época em que o espaço doméstico era estritamente protegido de estranhos:

(...) naquela época ninguém esperava isso. Cada casa era uma espécie de fortaleza em miniatura, um reduto inexpugnável. Eu mesmo não podia convidar amigos, porque minha mãe sempre dizia que estava tudo sujo. Não era verdade, porque a casa reluzia, mas eu pensava que talvez houvesse certo tipo de sujeira que simplesmente eu não distinguia, que quando fosse grande quem sabe visse camadas de pó onde agora não via mais que o piso encerado e madeiras lustrosas. (ZAMBRA, 2003, p. 16)

E a mudança de comportamento, com a decaída do regime:

Pedi a Claudia que me contasse o que havia acontecido: de que maneira as coisas tinham mudado para que agora minha presença fosse natural. É que as coisas estão mudando pouco a pouco, disse ela: muito lentamente as coisas estão mudando. Já não é necessário que você espione Raúl, pode vir me ver quando quiser, mas não é mais necessário que faça nenhum informe, insistiu, e não tive outro remédio senão ir embora remoendo um profundo desconcerto. (ZAMBRA, 2003, p. 25)

O hibridismo entre o discurso historiográfico e as memórias ficcionalizadas do narrador está presente em toda a construção narrativa de Zambra já que é possível acompanhar fatos que remetem ao auge e a decaída de Pinochet e mesmo ao processo de democratização, por meio das referências às eleições presidenciais em que Piñera é eleito presidente.

Diferente de Zambra, Vieira Júnior não delimita o seu romance em um marco histórico definido. No entanto, o foco narrativo se plasma no contexto dos conflitos pela terra no sertão do Brasil. Presentificado nesse contexto está o período escravocrata que, embora 
mais de cem anos após a Lei Áurea, ainda reverbera o rastro da violência senhoril e patriarcal do regime outrora abolido, mas que o presente não deixou de legitimar, já que “(...) foi com as casas de barro e nossos corpos como mobília que venderam a terra a um casal com dois filhos." (VIEIRA JÚNIOR, 2018, p. 186), e ainda "além da dívida de trabalho para com os senhores da fazenda, não havia nada para deixar para os filhos e netos." (VIEIRA JÚNIOR, 2018, p. 197).

O romance traz aspectos únicos da vida sofrida no sertão ao descrever o cotidiano de Zeca, um respeitado curador da região, e os filhos nas plantações; o sofrimento com a natureza, ora muita chuva, ora muita seca, e a situação das mulheres, que mesmo subjugadas lutam por seu espaço. A vida é cíclica e hierárquica no que tange à exploração: crianças exploradas pelos adultos; mulheres exploradas por seus maridos, maridos explorados pelos gerentes; gerentes explorados pelos patrões, como demonstrado no extrato abaixo:

O gerente queria trazer gente que $<<$ trabalhe muito $>>\mathrm{e}<<$ que não tenha medo de trabalho $>>$, nas palavras de meu pai, $<<$ para dar seu suor na plantação $>>$. Podia construir casa de barro, nada de alvenaria, nada que demarcasse o tempo de presença das famílias na terra. Podia colocar roça pequena para ter abobora, feijão, quiabo, nada que desviasse da necessidade de trabalhar para o dono da fazenda, afinal, era para isso que se permitia a morada. Podia trazer mulher e filhos, melhor assim, porque quando eles crescessem substituiriam os mais velhos. (...) Vi meu pai dizer para o meu tio que no tempo de seus avós era pior, não podia ter roça, não havia casa, todos se amontoavam no mesmo espaço, no mesmo barracão. (VIEIRA JÚNIOR, 2018, p. 42)

Além da dívida de gratidão que os prende à terra, o romance discute as relações dessa gente com as sessões de jarê e a importância de suas crenças ao mostrar a tentativa colonial de imposição do cristianismo para esses seres que, embora livres, ainda são considerados os bárbaros que "precisam" que o processo "civilizatório", orquestrado pelos brancos, salve suas almas.

No que diz respeito ao tempo histórico, em Torto Arado é possível perceber o início da sindicalização e as organizações para as lutas pela terra, seguindo a mesma sistemática de todas as lutas com o mesmo fim no país: a justiça positivada usada a favor dos grandes proprietários, a corrupção e a invenção de mentiras. Percebe-se, ainda, a entrada em vigor das leis ambientais quando o novo gerente proíbe o sepultamento dos mortos no cemitério da Viração pela proximidade com o rio, sob a justificativa de que "era crime contra as matas. Contra a natureza. Que o cemitério estava próximo ao leito do rio." (VIEIRA JÚNIOR, 2018, p. 189). É importante lembrar ainda que, quando a voz da entidade narra o romance, na terceira fase, tem-se um resumo da história do Brasil desde a colonização, passando pela dominação dos indígenas, a chegada dos negros e os ciclos extrativistas.

Um fato histórico determinado pelas ações dos personagens plasmado no romance é o início da demarcação das terras indígenas a partir da identificação dos moradores como indígenas “(...) dissemos que éramos índios. Porque sabíamos que mesmo que não fosse 
respeitada, havia lei que proibia tirar terra de índio. E também porque eles se misturavam conosco, indo e voltando de seu canto, perdidos de suas aldeias." (VIEIRA JÚNIOR, 2018, p. 187.).

Em Formas de voltar para casa, é possível acompanhar a condição de personagem secundário do narrador frente à movimentação política que é marcada na obra desde o início, quando, por querer brincar com as meninas na noite do terremoto, o narrador entra na cabana delas e é acusado de querer violá-las, sem nem compreender a dimensão do termo. É perceptível também a representação da figura de Pinochet, quase sempre apresentado simplesmente um personagem da televisão ou o nome indistinto grafado em uma frase pichada no muro.

Na época eu estava e sempre estive e sempre estarei a favor do Colo-Colo. Quanto a Pinochet, para mim era um personagem da televisão que conduzia um programa sem horário fixo, e eu o odiava por isso, pelos aborrecidos pronunciamentos em cadeia nacional que interrompiam a programação nas melhores partes. Tempos depois o odiei por ser filho da puta, por ser assassino, mas na época o odiava somente por aqueles intempestivos shows que meu pai olhava sem dizer palavra, sem conceder mais gestos que uma tragada mais intensa no cigarro que levava sempre grudado na boca. (ZAMBRA, 2014, p. 11)

A referência ao "time de Pinochet" marca o caráter evolutivo da personagem que, na infância, é a favor do clube que teve o militar como presidente honorário por imposição desde 1984, sem conhecer a dimensão política atrelada a isso. No entanto, o narrador continua simpático ao Colo-Colo mesmo no presente, quando já atingiu a compreensão de que o time, tido como único elemento capaz de unificar o Chile, pode ter atrasado o golpe do ditador e cujo jogador símbolo, Carlos Caszely, que teve familiares torturados, fez um dos atos mais memoráveis de resistência à ditadura ao se negar a cumprimentar o então presidente em público (ITURRIAGA, 2003).

Anos depois, na viagem de volta ao bairro da infância, o narrador e Claudia ressignificam suas memórias diante do Estádio Nacional do Chile, que serviu como Centro de detenção e execução durante a ditadura.

Caminhamos pela avenida Grécia, passamos pela Faculdade de Filosofia e então me lembro de alguma história ou centenas de histórias sobre aquele tempo, mas me sinto um pouco bobo, parece que tudo o que posso contar é irrelevante. Chegamos ao Estádio Nacional. O maior centro de detenção em 1973 sempre foi, para mim, nada mais que um campo de futebol. Minhas primeiras lembranças são meramente esportivas e alegres. Sem dúvida foi ali, nas arquibancadas desse estádio, que tomei meus primeiros sorvetes. A primeira lembrança de Claudia também é alegre. Em 1977 anunciou-se que Chespirito, o comediante mexicano, viria com todo o elenco de seu programa para dar um espetáculo no Estádio Nacional. Claudia tinha então quatro anos, via o programa e gostava muito. Seus pais se negaram, em princípio, a levá-la, mas no final cederam. Foram os quatro e 
Claudia e Ximena se divertiram bastante. Muitos anos mais tarde Claudia soube que aquele dia tinha sido, para seus pais, um suplício. Que a cada minuto pensaram no absurdo que era ver o estádio cheio de gente rindo. Que durante todo o espetáculo eles tinham pensado apenas, obsessivamente, nos mortos. (ZAMBRA, 2003, p. 61)

Há uma clara distinção entre as duas famílias e seus papéis na sociedade. Essa diferença também é sentida em outros momentos, quando o narrador se reconhece, durante as conversas na escola após a redemocratização, como pertencente a uma família da qual ninguém morreu, ninguém desapareceu ou foi torturado. Quando seu amigo, ainda criança, lembra que era o responsável por fazer cópias de La Batalla de Chile para os pais distribuírem aos membros do partido, o narrador afirma que não viveu nada disso. Por isso, como acusado por Eme, sua ex mulher que lê o manuscrito do romance, precisa se apropriar das memórias dos outros, inclusive a dela, para falar sobre o que não presenciou.

É Frederic Jameson quem nos adverte acerca da profundidade do evento histórico representado no romance:

Não (...) apenas a representação de um período de transição histórica, mas também, e em larga medida, a encenação de uma revolução e uma contrarrevolução; em outras palavras, de um daqueles eventos paradigmáticos, como a própria guerra, que sempre devem estar no centro de um romance histórico (...) para que ele se qualifique como tal (JAMESON, 2007, p. 188).

Nota-se, portanto, que o evento em questão há de ser capaz de mudar as estruturas sociais e que essas transformações têm que ser determinantes para o enredo. Em outras palavras, a vida privada das personagens fictícias estão interligadas com a esfera pública, como é possível perceber nas duas narrativas, cujo cotidiano dos personagens seguem as mudanças sociais e suas vidas são determinadas pelos fatos históricos.

Outra característica importante na conceituação do romance histórico é a transição da personagem de um mundo para outro. Em consonância com esse conceito, temos na personagem Belonísia - a muda - a representante dessa definição em Torto Arado. A personagem é descrita como representante do povo da lavoura. Desde cedo, ela contraria os planos do pai, que usa seu respeito enquanto exemplo da obediência e curador na fazenda para lutar pela construção da escola, tendo como sonho ver os filhos "com letras". Enquanto sua irmã orgulha o pai nesse sentido, Belonísia foge da escola para ir roçar.

Quando Bibiana, sua irmã, e o esposo voltam para a fazenda - representando o máximo da consciência política sindicalizada no romance - depois de anos morando na cidade, para organizar a revolução, começamos a perceber esse jogo de transição de mundos, já que Belonísia é a irmã próxima da terra, a que vai para lavoura "como um homem", então representando o povo simples. Embora bem demarcada nessa esfera social, ela tem uma fascinação intelectual pelo cunhado Severo que (...) caminhou por estradas, levantou sua voz em discursos, enfrentou os novos donos da terra. (VIEIRA JÚNIOR, 2018, p. 207.) 
(...) queria ouvir de Severo as explicações para o que vivíamos em Água Negra. Eram histórias que se comunicavam com meus rancores, com a voz deformada que me afligia e por vezes me despedaçava, com todo o sofrimento que nos unia nos lugares mais distantes. Que juntos, talvez pudéssemos romper com o destino que nos haviam designado. (JÚNIOR 2018, p. 139)

A impossibilidade de ser a personagem que levanta a bandeira de sua classe se dá por sua deficiência e consequente marginalização. Para o romance histórico isso é primordial, uma vez que o posicionamento parcial da personagem prejudicaria o trânsito entre um mundo e o outro (LUKÁCS, 2011). Belonísia, então, se configura como uma representante do povo da roça, aqueles que têm uma profunda relação de servidão com a terra de seus senhores, mas que contata o mundo do sindicalismo, dos conflitos por meio da vivência com o cunhado.

Já em Formas de voltar para casa, mesmo o narrador vivendo aquém do regime político, em um bairro projetado para demonstrar a distância da realidade com nomes de ruas fantasiosos e no seio de uma família sem posicionamento - portanto conivente com o regime, como ele conclui mais tarde -, o contato com o vizinho, a tarefa de segui-lo, a escola pichada e o professor traumatizado com as torturas que sofreu são exemplos de situações que permitem a ele o desenvolvimento de uma consciência histórica. Esse percurso se reflete na locomoção do narrador em cena, já que a cada contato com a realidade, a cada informação, mais longe de casa ele vai.

É como se, mesmo sem consciência dos fatos políticos a sua volta, a vida do narrador fosse regida pelas mudanças que estes causam em sua vida individual, tornando-o, ainda que sem papel ativo na história, um sobrevivente da ditadura. O resgate dessa inconsciência, por meio da memória do narrador, margeia o desenvolvimento de uma culpa individual e dá ao percurso um caráter evolutivo.

É importante verificar que esse caráter evolutivo é possível pela mobilidade social. Como é constatado, inclusive por sua mãe em um diálogo, o narrador vivencia relações sociais e até amorosas com pessoas de níveis sociais diferentes do seu. Esse trânsito de uma classe social, contemplado por Lukàcs (2011) na definição do herói médio, inicia com a visita que faz a casa de Cláudia e Magali - que tem dois banheiros - onde ele começa a ter contato com a realidade do país:

E Claudia? O que tem Claudia? Claudia é de que classe social? De que classe você é agora? Ela morou em Maipú, mas não é daqui. Vê-se que é mais refinada. Você também parece mais refinado que nós. Ninguém diria que é meu filho. Desculpa, diz minha mãe antes que eu possa responder a essa pergunta que, de todo modo, não saberia responder. Me serve mais mate e acende dois cigarros com a mesma chama. Vamos fumar aqui dentro, mesmo que seu pai não goste. Me passa um. Não é culpa sua, me diz. Você era muito jovem quando saiu de casa, aos vinte e dois anos. Aos vinte, mamãe. Aos vinte, aos vinte e dois, dá no mesmo. Muito jovem. Às vezes penso como seria a vida se você tivesse ficado em casa. Alguns ficaram. O menino ladrão, por exemplo. Ele ficou aqui e se tornou um ladrão. 
Outros também ficaram e agora são engenheiros. Assim é a vida: você se torna ladrão ou engenheiro. Mas não sei muito bem o que você se tornou. Eu também não sei o que meu pai se tornou, digo eu, de forma meio involuntária. Seu pai sempre foi um homem que ama a família. Foi e é. E como teria sido a vida se eu tivesse ficado, mamãe? Não sei. Teria sido pior, respondo. Minha mãe concorda. Talvez seja bom estarmos menos próximos, diz. Gosto de você como é. Gosto que defenda suas ideias. E gosto dessa menina, Claudia, para você, ainda que não seja da sua classe social. (ZAMBRA, 2003, p.69)

A ascensão social do filho promove o distanciamento da alienação dos pais e é perceptível por sua relação com a obra de Flaubert que, na infância, ao sofrer com a leitura obrigatória, faz uma ferrenha crítica ao ensino de literatura e seus professores reféns de manuais. Sem sucesso na atividade, ele se apropria do método do pai que, adepto à superficialidade, como haveria de ser alguém com o comportamento político que ele representa, o aconselha a "ler as primeiras páginas e em seguida as últimas, e só então, só depois de saber o começo e o final do romance, seguir lendo depressa." (ZAMBRA, 2014, p. 30).

O evento remete a outra característica do romance histórico contemporâneo: a intertextualidade. Além de dizer a respeito do repertório de leitura do pai que "ao que parece só tinha lido livros em que havia um assassino" (ZAMBRA, 2003, p. 30), diz sobre o narrador, que, já no presente, voltará a ler Madame Bovary "com devoção, com estranha fidelidade, como se neles pulsasse algo próprio, uma pista sobre o destino" (ZAMBRA, 2014, p. 29) representando assim uma mudança em sua consciência enquanto pessoa, e mais, a identificação com a burguesia, já que é essa a constatação que ele faz à sua mãe quando ela diz ter se identificado com alguns personagens do livro que lê:

Você gosta de Carla Guelfenbein? Não sei o que responder. Respondo que não. Não gosto desses livros, desse tipo de livros. Bom, não gostamos dos mesmos livros. Gostei do romance dela, El revés del alma. Me identifiquei com os personagens, me emocionei. E como é possível que se identifique com personagens de outra classe social, com conflitos que não são, que não poderiam ser os conflitos de sua vida, mamãe? Falo sério, muito sério. Sinto que e não deveria falar tão sério. Que não convém. Que não vou solucionar nada repreendendo meus pais pelo passado. Que não vou ganhar nada tirando de minha mãe o direito de opinar com liberdade sobre um livro. Ela me olha com uma mistura de irritação e compaixão. Com um pouco de enfado.

Você se engana, diz, talvez aquela não seja minha classe social, concordo, mas as classes sociais mudaram muito, todo mundo diz isso. E ao ler esse romance eu senti que sim, que aqueles eram meus problemas. Entendo que te incomode que eu diga isso, mas você deveria ser um pouco mais tolerante. (ZAMBRA, 2003, p. 69)

Encontramos aqui um ponto central para a discussão da pós modernidade, o antagonismo entre centro e periferia resgatado por meio do repertório de leitura como um retrato 
do insucesso da democracia social enquanto ideal e como a raiz da catástrofe do século XXI: a falta de consciência de classe. É nesse momento que a obra foge do foco narrativo, para construir, além da vida particular do narrador, uma crítica à pós modernidade e à ciclicidade dos regimes totalitários.

A ciclicidade, que caracteriza o romance histórico (MENTÓN, 1993), é percebida em Torto Arado na medida em que identificamos a homogeneidade na história das gerações que permeiam o enredo. A vida dos netos se ajustam a dos pais, que vivem as mesmas provações que os avós. Há inclusive comparações precisas entre os infortúnios de Belonísia e a avó Donana, e passagens que demarcam o medo de Bibiana de que as filhas cometam os mesmos erros que ela e a irmã na infância.

No que diz respeito ao caráter cíclico da história no plano narrativo de Zambra, se configura na repetição de fatos do passado: o terremoto, o reencontro com Claudia, os mesmos diálogos com a mãe em visita à sua casa e, por fim, a percepção de que no presente é ele o homem solitário e incompreendido dos quais os vizinhos desconfiaram no passado. Ademais, é característica desse gênero a metaficção, recorrente na obra de Zambra, já que o narrador deixa o leitor ciente das decisões que toma acerca do romance e das pausas que faz na escrita.

Voltei ao romance. Ensaio mudanças. Da primeira para a terceira pessoa, da terceira para a primeira, até para a segunda. Distancio e aproximo o narrador. E não avanço. Não vou avançar. Mudo de cenários. Apago. Apago muitíssimo. Vinte, trinta páginas. Esqueço esse livro. Me embriago aos poucos, adormeço. (ZAMBRA, 2003, p. 82)

Essa distinção entre os pais e o filho, entre Cláudia e a irmã, de dois lados que não se reconciliam, entre a passividade e a ação, reflete o movimento político chileno em sua dicotomia de mundos divididos, marcada e revivida em sua história, assim como outros países advindos de regimes totalitários que tem na polarização de lados o modus operandi da criação de um estado de exceção.

Considerando outra característica importante do romance histórico, que é a relação público e privada, já discutida aqui, voltamos a citar o exemplo do Cemitério da Viração em Torto Arado. A proibição do sepultamento neste cemitério, onde o povo alcança o máximo da sua constituição enquanto invisível social, já que podem ser enterrados mesmo sem terem registros de nascimento, significa muito mais do que um afronte à terra como propriedade, mas também uma ferida à dignidade dos mesmos enquanto seres humanos, já que aquele é o espaço de relação com seus antepassados.

É a partir da morte de Severo, claramente vítima de uma emboscada do proprietário das terras, que se escancara uma mudança social proveniente da dicotomia vida pública e privada. Após o velório, o povo revoltado pela perda do líder se encaminha para o cemitério:

O pequeno portão estava cerrado com corrente e cadeado. Pararam a marcha para decidir o que fazer. Bibiana, que passou quase todo o velório sem falar pediu 
para que o Cemitério da Viração fosse aberto, num tom de voz que muitos não conseguiram escutar. Seguiram o que julgaram ter ouvido. Foram muitas mãos agitadas sacudindo o portão velho, como muitos antepassados haviam agitado o corpo para fugir dos castigos e grilhões do cativeiro. O portão tombou no chão como uma corrente se desfazendo no ar. (VIEIRA JÚNIOR, 2018, p. 222)

Duas características do romance histórico podem ser retiradas desse extrato. A primeira é a percepção de que a história é forjada pelas massas e não, propriamente, pelo herói. A segunda é o alcance dos fatos narrados para além da vida do narrador. A quebra do portão representa a autonomia do povo. É a história sendo escrita pelos até então vencidos, que pela ação materializam um passo adiante na história dos direitos à terra no Brasil.

A queda do portão repercute a entrada em vigor da nova Constituição Federal que, embora ainda suscite muitas discussões, e pouco tenha alcançado no tentame de garantir a devolução das terras aos seus verdadeiros proprietários, em seu artigo art. 68 do Ato das Disposições Constitucionais Transitórias, dispõe que: "Aos remanescentes das comunidades de quilombos é reconhecida a propriedade definitiva, devendo o Estado emitir-lhes os respectivos títulos." (BRASIL, 1988).

É a partir da derrubada do portão que o povo passa a construir casas de alvenaria em um ato de rebeldia. Discursos são proferidos, mesmo na presença intimidadora do proprietário das terras, decisões, como a de se deitarem em frente às suas casas para que os tratores não as destruam são tomadas. Salomão, o dono das terras, é assassinado e, então, a exploração chega ao princípio do fim com o processo de reintegração de posse.

Sob a premissa de que a história não é natural, mas sim uma construção das massas, o romance histórico aqui analisado demonstra que a história age por meio da ação das personagens. Isso fica exemplificado de maneira clara no momento em que a "entidade" - a voz que narra o romance em sua última parte - se apossa do corpo das irmãs para matar o proprietário das terras. Essa formulação estética do destino, tanto das irmãs, quanto de Salomão, o proprietário, reverbera o destino do povo, que passa a alcançar direitos, até então suprimidos. O que Itamar Vieira Júnior plasma, sobretudo a partir dos episódios finais do seu romance, é o poder e o alcance da terra, não por seu fim enquanto propriedade privada, mas por sua relação com a dignidade da pessoa humana, só possível com o advento das lutas pelos Direitos Humanos.

Circunscrito na obra através das ações das personagens e suas jornadas está toda essa luta. Desde a primeira geração, ainda enquanto povo e burguesia lutavam juntas, buscando o livre comércio, passando pela segunda, ao tratar do direito à igualdade, e alcançando a terceira geração de direitos, agora preocupada com a dignidade da pessoa humana, onde se estabelece a luta pela terra não como propriedade em si, mas como elemento fundamental à vida. 


\section{CONSIDERAÇÕES FINAIS}

O retorno ao passado ainda é uma necessidade histórica. Ainda que a intenção seja construir uma identidade - latino-americana, neste caso - centrada nas verdades do país colonizado e não na de seu colonizador, é preciso voltar ao passado, em uma espécie de ato crítico-destruidor que refunde os alicerces, para só então construir outra vez.

Essa volta ao passado redireciona ao centro o que foi marginalizado. Se antes a história era a representação dos vencedores, agora é a massa que toma o protagonismo em detrimento aos heróis de outrora. O romance histórico, nesse sentido, é uma resposta política que busca a conscientização, não pelo que é dito, mas pelas ações das personagens.

Nos dois romances aqui analisados é possível perceber a história dos pais em confronto com a dos filhos, em meio a um processo de polarização ideológica tal qual aquele que outrora possibilitou o surgimento dos romances históricos. O posicionamento político em Zambra é motivo das brigas com os pais. Em Torto Arado, os movimentos na fazenda só começam, efetivamente, após a morte de Zeca Chapéu Grande, já que antes era preciso respeitar a gratidão que ele sentia pelos donos da terra. Essa polarização, representada pelas duas gerações frente ao sistema vigente - a dos pais, conformados, e a dos filhos, que agem movidos pelo desejo de mudanças - ultrapassa os limites da vida particular para, por meio da criação artística, alcançar a consciência social: escolher a neutralidade, o não agir, também é eleger um lado.

É neste ínterim, entre essas duas forças, que estão os heróis medianos de ambos os romances: o narrador em Formas de voltar para casa e Belonísia em Torto Arado. É a literatura dos pais que transforma os filhos em protagonistas e, neste sentido, o fato histórico determina o sujeito, uma vez que a falta de consciência de uma geração, imobilizada por esses fatos, implica na ação da outra, que, ao escolher o inverso do exemplo dado antes, modificam a vida coletiva. A vida individual de uma geração perde o protagonismo com a ascensão de uma luta coletiva.

A geração dos pais, em ambos os romances, reflete o mundo velho em declínio que, em uma conjuntura da história enquanto processo, enquanto precondição do presente, cede lugar à revolução, concebida como parte indispensável do progresso humano e que possibilitará o surgimento de um novo mundo, resultante desse choque. Circunscrita nessa luta de classes, esteticamente organizada, está a metáfora de cobrir e o mostrar a cara com o qual iniciamos essa análise.

É esse o principal elemento resgatado pela análise. O romancista histórico não deixará de buscar elementos no esquema tradicional - como a composição desses heróis médios na definição de Lukàcs, por exemplo, por uma questão de passagem do tempo, principalmente porque a própria vida está circunscrita em uma esfera cíclica em que fatos históricos, embora distintos, repetem seus efeitos de geração após geração. Assim, resgatando elementos ora do esquema tradicional, ora do (pós)moderno, ambos os romances se prestam ao resgate da violência simbólica e a conscientização do sujeito do presente ao provar que é através das escolhas resultantes dessas contradições, dessa movimentação histórica que se faz no cotidiano, que há uma alteração nas condições de vida.

Ao transformar em sujeitos de direitos - inclusive o de se resguardarem do memori- 
cídio - os grupos tradicionalmente silenciados, o romance histórico impõe uma força ao povo, por vezes desconsiderada. Isso porque é através das mudanças sociais, possíveis pelo protagonismo desse mesmo povo, que a história se reescreve. 


\section{REFERENNCIAS}

AÍNSA, F. Reescribir el pasado. Historia y Ficción en América Latina. Caracas: Celarg, 2003.

BRASIL. Constituição (1988). Constituição da República Federativa do Brasil. Brasília, DF: Senado Federal: Centro Gráfico, 1988

CANDIDO, A. O direito à literatura. In: . Vários Escritos. 5 ed. Rio de Janeiro: Ouro sobre Azul/

São Paulo: Duas Cidades, 2011.

CORALINA, C. Poemas dos becos de Goiás e estórias mais. 18. ed. São Paulo: Global, 1985

ITURRIAGA, J. E. Proletas, Limpios, cobardes y burgueses. El fútbol en 1973. En: 1973. La vida cotidiana de un año crucial. Planeta. 2003. p. 138

JAMESON, F. O romance histórico ainda é possível? Novos Estudos. CEBRAP, São Paulo, n. 77, p. 205220, mar. 2007.

JUNIOR, I. V. Torto Arado. Afralgide: Leya, 2018.

LACAPRA, D. História e o romance. Revista de História (Campinas, IFCH/UNICAMP, 1991, nº 2/3)

LUKÀCS, G. Teoria do Romance. Tradução de José Marcos Mariani de Macedo. $2^{\text {a }}$ ed. São Paulo: Editora 34, 2009.

LUKÀCS, G. O romance histórico. Tradução Rubens Enderle. São Paulo: Boitempo, 2011.

MÁRQUEZ RODRÍGUEZ, A. Historia y ficción en la novela venezolana. Caracas: Monte Ávila, 1991.

MATA-INDURAÍN, C. La novela histórica. Teoría y comentários. Pamplona: Eunsa, 1995.

MENTON, S. La nueva novela histórica de la América Latina, 1979- 1992. México: FCE, 1993.

NUNES, B. Narrativa histórica e narrativa ficcional. In: RIEDEL, Dirce C. Narrativa: ficção e história. Rio de Janeiro: Imago, 1988, p. 9-35.

ZAMBRA, A. Formas de voltar para casa. São Paulo: Cosac Naify. 2014. 